obscuration of an infra-red ray in time with Schneider's breathing, to which our correspondent specially referred.

\section{Tenth Satellite of Jupiter}

According to Science Service, Dr. H. M. Jeffers of the Lick Observatory photographed a very faint object (of the nineteenth magnitude) which appears to have the same motion in the sky as the eighth satellite of Jupiter. The new satellite has presumably a diameter even smaller than that of the eighth, which is only 25 miles. If the new object's identity as a satellite of Jupiter is established, that planet will lead the field as a satellite holder, Saturn having but nine. Jupiter is now very prominent in the evening sky, and the four brightest satellites can be seen with a modest telescope. But for the glare from the planet they should just be visible to the naked eye in a good climate. (It has been stated that certain Kalahari natives can distinguish Jupiter's satellites with the naked eye.) With the most powerful telescope, however, nobody will see the new satellite of the nineteenth magnitude. It can only be photographed by giving fairly long exposures on a large telescope.

\section{Announcements}

Maurice, Duc DE Broglie, has been elected to a seat in the Académie Française, the section of the Institut de France which concerns itself with language and literature. M. de Broglie is well-known as a physicist for his work on X-ray spectra and allied subjects, for which he was awarded the Hughes Medal of the Royal Society in 1928. For the past ten years he has been académicien libre of the Académie des Sciences, which is the scientific section of the Institut de France.

THE second conversazione this year of the Royal Society will be held at the Society's rooms on June 20 at 9 p.m.

IT is announced in the Times that Sir Charles Brooke, Rajah of Sarawak, has given $£ 20,000$ towards the building scheme for the Imperial Forestry Institute at Oxford.

THE research laboratories of the Callenders Cable and Construction Co., Ltd., 38, Wood Lane, Shepherd's Bush, London, W.12, will be opened by Lord Rutherford on Friday, June 22.

The annual general meeting of the British Science Guild will be held in the lecture theatre of the Royal Society of Arts on Tuesday, June 12, at 4 p.m. Following the meeting, a popular lecture entitled "Friction" will be delivered by Prof. E. N. da C. Andrade.

At the anniversary meeting of the Linnean Society of London held on Thursday, May 24, the following officers were elected :-President: Dr. W. T. Calman; Treasurer: Mr. F. Druce ; Botanical Secretary: Mr. John Ramsbottom ; Zoological Secretary : Dr. Stanley W. Kemp. The Linnean Gold Medal was presented to Sir Sidney Harmer.
THE secretary of the University Press of Liverpool, referring to the notes on the centenary of the Liverpool Medical School in Nature of May 19, p. 753, asks us to state that "The Liverpool Medical School 1834-1934" is the production of the University Press, and is published by the Press, with Messrs. Hodder and Stoughton, Ltd.

UNDER the title of "The Silk Industry of Japan" the Imperial Council of Agricultural Research (India) has issued (1933) a comprehensive monograph by Mr. C. C. Ghosh on this subject. It is primarily based upon the results of a study made by Mr. Ghosh in Japan in 1929 and provides a useful illus. trated account of the biological, technical and administrative aspects of the industry. The work can be obtained through booksellers, or through the Office of the High Commissioner for India, Aldwych, London, W.C.2, price $6 s .9 d$.

Applications are invited for the following appoint. ments, on or before the dates mentioned :-A lecturer in physics and elementary science (including nature study) at the City of Leeds Training College-The Director of Education, Education Department, Calverley Street, Leeds (June 5). A teacher of physical chemistry at the Northern Polytechnic, Holloway, London, N.7-The Clerk (June 6). An assistant professor and a lecturer in mathematics at the Royal Naval College, Greenwich - The Adviser on Education, Admiralty, Whitehall, S.W.1 (June 11). A lecturer in mathematics at tho Constantine Technical College-The Director of Education, Education Offices, Middlesbrough (June 9). A temporary assistant lecturer in agricultural botany at the University College of North Wales, Aberyst. wyth-Prof. R. G. Stapledon, Agricultural Buildings, Alexandra Road, Aberystwyth (June 12). A lecturer in chemistry at the Medway Technical College, Gardiner Street, Gillingham, Kent-The District Education Officer, 15, Mew Road Avenue, Chatham (June 16). A part-time assistant (biology) in the Department of History and Method of Science at University College, Gower Street, London, W.C.IThe Secretary (June 16). A lecturer in political science at the London School of Economics and Political Science, Houghton Street, Aldwych, W.C.2 -The Secretary (June 22). Examiners in various branches of science in the University of LondonThe External Registrar, University of London, South Kensington, S.W.7 (July 8). A professor of mining and a professor of geology in the University of the Witwatersrand, Johannesburg-The Secretary, Office of the High Commissioner, South Africa House, Trafalgar Square, London, W.C.2 (July 14). A senior lecturer in psychology, a lecturer in geology and a lecturer in mathematics (at Pietermaritzburg) and a lecturer in civil engineering, a lecturer in mathematics and chemistry and a lecturer in English and psychology (at Durban) in Natal University College-The Registrar, Natal University College, Pietermaritz. burg (Aug. 1). A technical adviser on industries to the Bureau of Industry and Commerce, Ceylon-The Crown Agents for the Colonies, 4, Millbank, London, S.W.1. 